\title{
Fatty Acid and Amino Acid Profile of Indigenous Cluster Ecotypes of Kenyan Free- ranging Chicken
}

\author{
${ }^{*}{ }^{1}$ Benard O. Oloo, ${ }^{1}$ Symon M. Mahungu, ${ }^{2}$ Alexander K. Kahi, and ${ }^{3}$ Eric Amonsou \\ ${ }^{1}$ Department of Food Science and Technology, Egerton University, P.O Box 536, Egerton, Kenya \\ ${ }^{2}$ Department of Animal Science and Veterinary Science, Egerton University, P.O Box 536, Egerton, Kenya \\ ${ }^{3}$ Department of Biotechnology and Food Technology, Durban University of Technology, Durban, South \\ Africa. \\ *Corresponding author: Bernard O. Oloo: olooo.odhiambo@gmail.com \\ https://doi.org/10.37512/100
}

\begin{abstract}
An experiment was conducted to determine amino acid and fatty acid profile of indigenous chicken reared in Kenya under a free range feeding system. Five cocks of each ecotype were purchased, slaughtered and transported to JKUAT and Durban University of Technology, within 12 and 24 hours respectively in an insulated box containing ice. Amino acid profile was estimated using Pico Tag by hydrolysis with acid for 24 hours, derivatized and analyzed by reverse phase HPLC. Fatty Acid Methyl Esters (FAME) were synthesized by a direct/one-step extraction transesterification method. FAME were then separated and quantified using gas chromatography. The amino acid and fatty acid profile of indigenous chicken in Kenya was affected by the ecotype as well as the part of the chicken (breast or thigh). The amino acid profile of experimental chicken revealed values higher than the RDA. The ratio of $\square-6: \square-3$ though higher than $4: 1$, demonstrated that the consumption of indigenous free ranging chicken meat is likely to give favourable health outcomes.
\end{abstract}

KEY WORDS: Fatty acid, amino acid, indigenous chicken, Kenya

\section{INTRODUCTION}

Poultry in Kenya play an important socio-economic, food and nutrition security roles in most households and especially in rural areas. Kenyan poultry population is estimated at 42.4 million birds (FAO, 2014) out of which $75 \%$ are local indigenous chicken. The remaining $22 \%$ is broilers while the rest is breeding stock and spent layers. Meat quality and palatability is affected by several factors. A major one is the fatty acid composition in the muscles and adipose tissue (Hoffman et al., 2005). The amino acid profile is also responsible for nutritional and functional quality of chicken meat. The most common rearing method for indigenous chicken is through the free range backyard system. According to (Pavlovski et al., 2013) chicken meat from intensive broiler production differs in quality from native breeds and those in a free range system. Intensification of native/indigenous chicken rearing has been on the increase for the past 20 years. Rearing native chicken under an intensive system in Serbia has been studied by (Bogosavljevic-Boskovic et al.., 2010; Milošević et al., 2003; and Blagojević et al., 2009); Pavlovski et al., 2013). Because of their work it is now considered that to develop an intense meat flavour, broilers should be kept under free range production system, a practice that is currently becoming common in Europe and the USA. This concept is also supported by the strong animal welfare groups (Dawkins, 2003). The demand for poultry meat has been estimated to triple in Africa, a trend that is likely to be replicated in other parts of the world by the year 2030 (Zootecnica, 2016; Heinz et al., 2007).

Food nutrition data is important to international 
organizations, private individual, food aid programmes, and epidemiologist who often relate patters of disease with the dietary components and nutritional assessment of individual intake and diet counselling (Rand et al., 1991; Almeida et al., 2006). Although the USDA and FAO have published papers with nutrition tables of chicken, these are from the data collected from the chicken reared in the USA and Europe. The composition of total fat, Saturated Fatty Acids (SFA) and Mono Unsaturated Fatty Acids (MUFA) are independent risk factors for all cause cardio-vascular disease (Leosdottir et al, 2005). The American Diabetic Association (2005) advises to limit total daily energy intake from fat to $<30 \%$. They also recommend that the SFA and Trans-fatty acids should contribute no more than $10 \%$ of total daily energy intake. It has already been demonstrated that replacing red meat with chicken may result in significant decrease in apolipoprotein $\mathrm{B}$ and total cholesterol levels in type 2 diabetic patients (Gross et al., 2002). This effect is probably an attribute of the higher PUFA content of chicken meat as compared to beef. At the same time, the beneficial attributes of PUFA is dependent on the ratio of omega 6 fatty acids to that of omega 3. An ideal ratio is often agreed as 4:1 This ratio is often favorable in poultry meat depending on diet (Marangoni et al., 2015a).

With regard to quality of protein food sources, the value of the amino acids measured in terms of the amino acid scores, essential amino acid index and the protein digestibility corrected amino acid scores is important to the understanding of the nutritive value of a given protein in the diet (FAO/WHO, 1985). At the same time, the low levels of collagen in poultry meat is a good indicator of its digestibility and hence biological value (Marangoni et al., 2015). In spite of the apparent benefits of poultry meat to nutrition and especially with regard to provision of essential fatty acids and amino acids, the nutritive composition of these factors in indigenous chicken in Kenya is yet to be reported and documented. This study therefore evaluated the nutritive value of indigenous chicken meat in Kenya by determining the fatty acid and amino acid profiles of three ecotypes.

\section{Materials and Methods}

\section{Fat Content Determination}

The crude fat content was determined by Soxhlet extraction, using the standard method of the Association of Official Analytical Chemists (AOAC, 2005).

\section{Fatty acid Analysis}

Fatty profile acid analysis was carried out according to AOAC (2005) as modified by (Indarti, 2015). Fatty Acid Methyl Esters (FAME) were synthesized by a direct/one-step extraction transesterification method. A tenth of a gram of sample was mixed with $2 \mathrm{ml}$ of a mixture of methanol and sulfuric acid $(85: 15, \mathrm{v} / \mathrm{v})$ and $2 \mathrm{ml}$ of chloroform. Samples were heated to $100^{\circ} \mathrm{C}$ for $30 \mathrm{~min}$ and cooled to room temperature in a desiccator. Then, $1 \mathrm{ml}$ of distilled water was added to the mixture, followed by vortexing for $1 \mathrm{~min}$. The mixture was allowed to separate and the organic phase (top layer) containing FAME was then transferred and dried with anhydrous $\mathrm{Na}_{2} \mathrm{SO}$. Samples were stored in a freezer $\left(-20^{\circ} \mathrm{C}\right)$ while awaiting Gas Chromatography (GC) analysis.

FAME were separated and quantified using a gas chromatography system (Automatic System XL, Perkin ElmerTM, Norwalk, Connecticut, USA) equipped with a flame ionization detector and a 30-m x 0.25 -mm fused silica capillary column (Omegawax 250, Supelco ${ }^{\mathrm{TM}}$, Bellefont, USA). Helium was used as the carrier gas, while hydrogen and compressed air was used for Flame Ionization Detection. The oven temperature was programmed to rise from $50-220^{\circ} \mathrm{C}$ at a rate of $4^{\circ} \mathrm{C} \mathrm{min}^{-1}$ and then held at $220^{\circ} \mathrm{C}$ for 35 $\mathrm{min}$. The injector and detector temperatures were set to $250^{\circ} \mathrm{C}$ and $260^{\circ} \mathrm{C}$, respectively. Individual fatty acids were identified by comparison to known standards (Supelco 37 Component FAME Mix; Supleco) and the areas beneath the identified chromatographic peaks calculated by integration. Saturated Fatty Acids (FSA), Mono-Unsaturated Fatty acids (MUFA) and Poly-Unsaturated Fatty acids (PUFA) and their ratios were calculated from the fatty acid composition results. 


\section{Determination of Amino Acid Profile}

The total amino acid content of the 17 different amino acids in the sample are reported in duplicate and reported as $\mathrm{g} / 100 \mathrm{~g}$ sample as is. Total amino acid profile (excluding Tryptophan, Cysteine and Methionine) were determined on lyophilized, ground and homogenous samples by SAGL In-house method 009: as adopted from Pico-TagTM method as described by (Bidlingmeyer et al., 1984). Samples were hydrolyzed with acid for 24 hours, then derivatized and analyzed by reverse phase HPLC. Cysteine and methionine were analysed

\section{RESULTS AND DISCUSSION}

Table 1 shows the amino acid profiles (total essential and non-essential amino acids) of the indigenous chicken ecotypes, from three locations and two body parts. Except for the amino acids Histidine and Lysine which were higher in the breasts than in the thigh muscles for all the ecotypes, there were no significant differences on the amino acid profile of the breasts and thighs $(\mathrm{P}>0.05)$. The values reported for Methionine (minimum of $6.77 \mathrm{~g} / 100 \mathrm{~g}$ ), and Lysine (minimum of $7.76 \mathrm{~g} / 100 \mathrm{~g}$ ) which are limiting amino acids in cereals and legumes were very high in the chicken. This supports the assertion that chicken is a good source of high quality protein and confirms that Kenyan indigenous chicken under free range are equally a good source of the same. Considerable amounts of Lysine, Aspartic acid and Glutamic acid were found in all the three ecotypes-the trend was observed in the breasts and thighs. The high level of Glutamic acid (Figure 1) which has been demonstrated to correspond to the taste is theorized to be a contributor to the claimed better taste of indigenous chicken. This result is in line with the finding of Wattanachant et al. (2004) and Aronal et al. (2012) who reported high values for these three amino acids. They also reported very high values of leucine in the breast and thighs of chicken, a result which is supported by our findings. Protein quality in human nutrition is closely related to the efficiency of protein utilization in the human digestive system. This is usually a factor of protein digestibility, quantity and type of the amino acid.

Table 1: The essential amino acid profile of chicken body parts, ecotype vs. FAO/WHO recommended intake.

\begin{tabular}{llllllll}
\hline $\begin{array}{l}\text { Amino } \\
\text { acid }\end{array}$ & \multicolumn{2}{l}{ Chicken parts } & Ecotype & & \multicolumn{2}{l}{$\begin{array}{l}\text { FAO/WHO } \\
\text { recommendation } \\
\text { for adults }\end{array}$} & $\begin{array}{l}\text { FAO/WHO } \\
\text { recommendation } \\
\text { for children }\end{array}$ \\
\hline His & $2.96 \pm 0.03^{\mathrm{a}}$ & $2.15 \pm 0.13^{\mathrm{b}}$ & $2.51 \pm 0.40$ & $2.46 \pm 0.52$ & $2.69 \pm 0.30$ & 1.6 & 1.9 \\
Lys & $9.02 \pm 0.26^{\mathrm{a}}$ & $7.76 \pm 0.24^{\mathrm{b}}$ & $7.95 \pm 0.56$ & $8.43 \pm 0.75$ & $8.79 \pm 0.58$ & 1.6 & 5.8 \\
Met & $7.96 \pm 0.19$ & $6.77 \pm 0.89$ & $6.79 \pm 0.84$ & $6.90 \pm 1.09$ & $8.42 \pm 0.13$ & 1.7 & 2.7 \\
Val & $4.33 \pm 0.02$ & $3.91 \pm 0.22$ & $4.04 \pm 0.33$ & $3.99 \pm 0.31$ & $4.34 \pm 0.01$ & 1.5 & 3.5 \\
Ile & $3.91 \pm 0.04$ & $3.62 \pm 0.17$ & $3.67 \pm 0.29$ & $3.69 \pm 0.16$ & $3.94 \pm 0.02$ & 1.3 & 2.8 \\
Leu & $7.25 \pm 0.10$ & $6.70 \pm 0.41$ & $6.81 \pm 0.60$ & $6.73 \pm 0.35$ & $7.41 \pm 0.11$ & 1.9 & 6.6 \\
Phe & $3.42 \pm 0.26$ & $3.50 \pm 0.27$ & $3.50 \pm 0.42$ & $3.25 \pm 0.17$ & $3.63 \pm 0.38$ & 1.6 & 6.3 \\
Thr & $4.20 \pm 0.09$ & $4.04 \pm 0.23$ & $4.03 \pm 0.35$ & $4.01 \pm 0.05$ & $4.33 \pm 0.16$ & 0.9 & 3.4 \\
Total & $\mathbf{4 3 . 0 5}$ & $\mathbf{3 8 . 5}$ & $\mathbf{3 9 . 3}$ & $\mathbf{3 9 . 4 6}$ & $\mathbf{4 3 . 5 5}$ & &
\end{tabular}




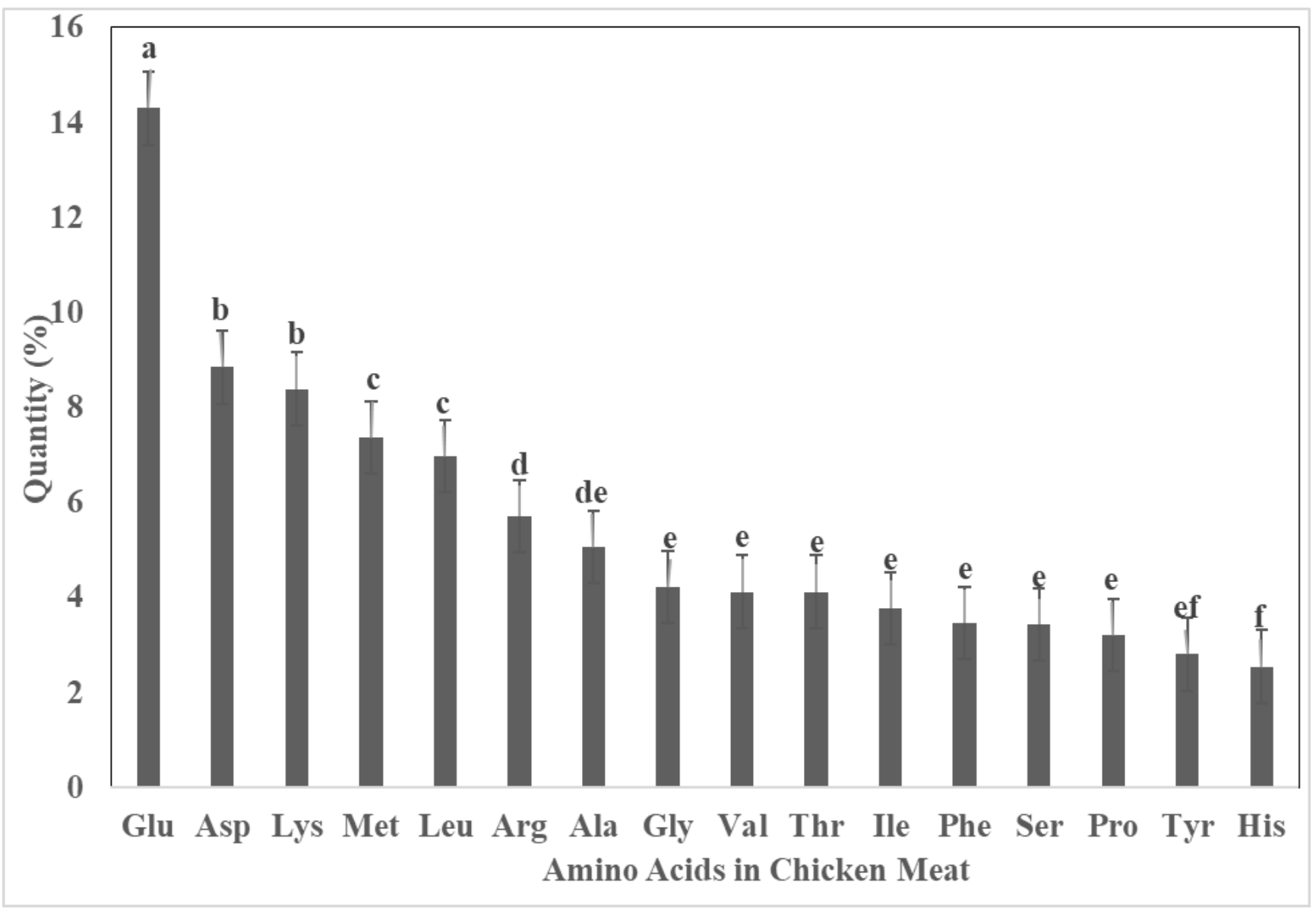

Figure 1: Amino acid composition of chicken meat (average of breast and thigh).

Glutamic acid has been reported to have a significant effect on the taste of meat. The higher levels reported in this study and supported by reports from others studies may be one of the factors that is responsible for the better taste already reported in many parts of the world when indigenous chicken and the broiler are compared (Farmer, 1999). Histidine value even though being the lowest was still reported at a value that is more than the recommended value by the WHO/FAO (2007) for both adults and children (Table 1).

\section{Amino acid-chemical scores}

In the current study, the values of the PDCAAS for all the amino acids from the chicken had a value greater than unity for both the breasts and the thighs. The protein score reflects its amino acid (AA) content in comparison with the ideal protein (Aronal et al., 2012). Normally egg white and milk proteins are considered the ideal proteins due to their high digestibility and hence the rest of the amino acids are compared against these two (FAO/WHO, 1985). However, when there is a need to know the use of an amino acid by the organism, it is necessary to do a correction of the score value by protein digestibility (PDCAAS) (Marangoni et al., 2015a). Poultry meat like that of milk and egg are referred to as high quality proteins, as they have a PDCAAS of 1 or very close to one. This is unlike the legumes and vegetable sources which have PDCAAS of up to 0.5 while wheat and beans are at 0.75 (Marangoni et al., 2015). 


\section{Fatty acid profile of Kenyan indigenous chicken}

The fatty acid profile of the breast meat of the three ecotypes are presented in Table 2 . Poultry meat is a major contributor of triacylglycerols (TAGs), PUFAs MUFAs, and SFAs in diets. Within the Kakamega ecotype, the palmitic acid composition was highest followed by the oleic and linoleic fatty acid compositions, respectively. The value of Caprilic acid at $0.04 \%$ was the lowest. For Naivasha ecotype, the oleic acid content was highest followed by palmitic and then linoleic acid. The lowest was the composition of Arachidonic acid. For Taita ecotype, oleic acid, acid composition was highest followed by palmitic and then linoleic acid composition. Among the three ecotypes, the composition of the palmitic acid was significantly different in the Naivasha than in the Kakamega and Taita ecotypes. Palmitic acid is a saturated fatty acid and one of the most abundant in nature. The composition of stearic acid was equally significantly higher in the Naivasha than in the Kakamega but not in the Taita ecotypes. Factors affecting fatty acid content of poultry are: animal breed, external and internal fat levels, climate, and rearing methods (Broganolo, 1997. These factors are more often than not determined by the regions and resultant cultural, management and feeding practices of the people.

Table 2: Fatty acid composition (\%) of breast meat of three indigenous chicken ecotypes

\begin{tabular}{lrrr}
\hline Fatty acid & Ecotype & Naivasha & \multicolumn{1}{c}{ Taita } \\
\hline Kakrylic & $0.04 \pm 0.02^{\mathrm{a}}$ & $0.88 \pm 0.51^{\mathrm{a}}$ & $0.14 \pm 0.07^{\mathrm{a}}$ \\
Capric & $0.57 \pm 0.28^{\mathrm{a}}$ & $0.42 \pm 0.11^{\mathrm{a}}$ & $0.02 \pm 0.01^{\mathrm{a}}$ \\
Lauric & $0.42 \pm 0.17^{\mathrm{a}}$ & $0.26 \pm 0.03^{\mathrm{a}}$ & $0.18 \pm 0.08^{\mathrm{a}}$ \\
Myristic & $0.76 \pm 0.19^{\mathrm{a}}$ & $0.76 \pm 0.04^{\mathrm{a}}$ & $0.99 \pm 0.14^{\mathrm{a}}$ \\
Palmitic & $20.20 \pm 0.71^{\mathrm{a}}$ & $17.88 \pm 0.59^{\mathrm{b}}$ & $20.02 \pm 0.64^{\mathrm{a}}$ \\
Palmitoleic & $1.73 \pm 0.14^{\mathrm{a}}$ & $1.51 \pm 0.15^{\mathrm{a}}$ & $1.74 \pm 0.16^{\mathrm{a}}$ \\
Stearic & $9.81 \pm 0.16^{\mathrm{b}}$ & $11.65 \pm 0.78^{\mathrm{a}}$ & $10.76 \pm 0.37^{\mathrm{a}}$ \\
Oleic & $19.55 \pm 0.60^{\mathrm{a}}$ & $20.59 \pm 0.67^{\mathrm{a}}$ & $20.33 \pm 0.59^{\mathrm{a}}$ \\
Linoleic & $15.06 \pm 0.95^{\mathrm{a}}$ & $13.12 \pm 0.59^{\mathrm{a}}$ & $15.75 \pm 0.75^{\mathrm{a}}$ \\
Linolenic & $0.89 \pm 0.19^{\mathrm{a}}$ & $0.84 \pm 0.05^{\mathrm{a}}$ & $0.58 \pm 0.08^{\mathrm{a}}$ \\
Arachidic & $0.32 \pm 0.21^{\mathrm{a}}$ & $0.19 \pm 0.09^{\mathrm{a}}$ & $0.13 \pm 0.04^{\mathrm{a}}$ \\
Arachidonic & $10.22 \pm 0.73^{\mathrm{b}}$ & $13.11 \pm 0.29^{\mathrm{a}}$ & $10.13 \pm 0.29^{\mathrm{b}}$ \\
EPA & $0.76 \pm 0.14^{\mathrm{a}}$ & $0.80 \pm 0.10^{\mathrm{a}}$ & $1.10 \pm 0.05^{\mathrm{a}}$ \\
DHA & $2.31 \pm 0.36^{\mathrm{a}}$ & $1.40 \pm 0.10^{\mathrm{b}}$ & $1.66 \pm 0.10^{\mathrm{b}}$ \\
\hline
\end{tabular}

Legend: Eicosapentanoic acid (EPA) and Decosahexaenoic acid (DHA)

Fat content and fatty acid profiles of TAGs in on the unique conditions of the farmers. This muscles strongly correlate to meat quality especially suggestion was also made by Cherian et al. (2002) tenderness, juiciness and flavor (Wood et al., 2008). who in their study determined muscle fatty acid Although Wattanachant et al., (2004), reported higher composition and thiobarbituric acid-reactive content of saturated fatty acids and lower PUFA in substances in broilers fed on different cultivars of indigenous chicken muscle than in broilers, sorghum. They noticed significant difference in these (Jaturasitha et al., 2008) found the opposite results. In values for chicken fed on different cultivars. The fatty the current study, the fatty acid profile was found to differ by ecotype $(\mathrm{p} \leq 0.05)$ possibly due to the different feeds fed to the different genotypes based acid profile of the thigh meat of the three ecotypes is given in table 3.

For the thigh meat, oleic fatty acid was highest $(p \leq 0.05)$ in the Kakamega ecotype followed by 
palmitic acid and then linolenic acid. The lowest was capric acid at $0.18 \pm 0.05 \%$. With regard to the Naivasha ecotype, oleic acid was highest followed by palmitic and then linoleic acid. The lowest fatty acid was Capric acid at $0.06 \pm 0.03 \%$. For the Taita ecotype, oleic acid was the highest followed by linoleic and then palmitic acid and the lowest was capric acid at $0.1 \pm 0.05 \%$. Compared across the ecotypes, significant differences $(p \leq 0.05)$ were noted on Caprylic acid between Naivasha, Taita and Kakamega ecotype. Lauric acid composition was also significantly higher in Kakamega than in the Naivasha and Taita ecotypes. Myristic acid composition was significantly different for Naivasha and Kakamega ecotypes from the Taita ecotype. Finally, the acid docosahexaenoic acid (DHA) composition was significantly highest in Kakamega than in Naivasha and Taita. The DHA fatty acid is part of the long chain omega 3 fatty acids that also include eicosapentaenoic acid (EPA), and decosapentaenoic acid (DPA) (Haug et al., 2011).

Table 3: Fatty acid composition (\%) of thigh meat of three indigenous chicken ecotypes

\begin{tabular}{lccc} 
Fatty acid & $\begin{array}{l}\text { Ecotype } \\
\text { Kakamega }\end{array}$ & Naivasha & \multicolumn{1}{c}{ Taita } \\
\hline Caprylic & $0.27 \pm 0.07^{\mathrm{b}}$ & $0.81 \pm 0.19^{\mathrm{a}}$ & $0.44 \pm 0.16^{\mathrm{ab}}$ \\
Capric & $0.18 \pm 0.05^{\mathrm{a}}$ & $0.06 \pm 0.03^{\mathrm{a}}$ & $0.10 \pm 0.05^{\mathrm{a}}$ \\
Lauric & $0.23 \pm 0.03^{\mathrm{a}}$ & $0.10 \pm 0.02^{\mathrm{b}}$ & $0.13 \pm 0.04^{\mathrm{ab}}$ \\
Myristic & $0.63 \pm 0.10^{\mathrm{ab}}$ & $0.84 \pm 0.06^{\mathrm{a}}$ & $1.12 \pm 0.14^{\mathrm{b}}$ \\
Palmitic & $18.34 \pm 0.61^{\mathrm{a}}$ & $16.58 \pm 0.49^{\mathrm{a}}$ & $18.47 \pm 0.70^{\mathrm{a}}$ \\
Palmitoleic & $2.00 \pm 0.15^{\mathrm{a}}$ & $2.20 \pm 0.18^{\mathrm{a}}$ & $2.17 \pm 0.25^{\mathrm{a}}$ \\
Stearic & $12.97 \pm 0.33^{\mathrm{a}}$ & $13.72 \pm 0.53^{\mathrm{a}}$ & $12.23 \pm 0.48^{\mathrm{a}}$ \\
Oleic & $19.85 \pm 0.63^{\mathrm{a}}$ & $23.53 \pm 1.31^{\mathrm{a}}$ & $22.44 \pm 1.35^{\mathrm{a}}$ \\
Linoleic & $15.73 \pm 0.30^{\mathrm{a}}$ & $15.98 \pm 0.97^{\mathrm{a}}$ & $19.18 \pm 2.06^{\mathrm{a}}$ \\
Linolenic & $0.59 \pm 0.04^{\mathrm{a}}$ & $1.51 \pm 0.51^{\mathrm{a}}$ & $0.78 \pm 0.11^{\mathrm{a}}$ \\
Arachidic & $0.15 \pm 0.03^{\mathrm{a}}$ & $0.18 \pm 0.03^{\mathrm{a}}$ & $0.22 \pm 0.10^{\mathrm{a}}$ \\
Arachidonic & $10.64 \pm 0.40^{\mathrm{ab}}$ & $12.19 \pm 0.67^{\mathrm{a}}$ & $9.29 \pm 0.88^{\mathrm{b}}$ \\
EPA & $1.18 \pm 0.24^{\mathrm{a}}$ & $0.60 \pm 0.05^{\mathrm{a}}$ & $0.91 \pm 0.18^{\mathrm{a}}$ \\
DHA & $2.45 \pm 0.21^{\mathrm{a}}$ & $0.90 \pm 0.10^{\mathrm{b}}$ & $1.55 \pm 0.24^{\mathrm{b}}$ \\
\hline
\end{tabular}

Legend: Eicosapentanoic acid (EPA) and Decosahexaenoic acid (DHA)

Among the three ecotyes, the values of SFA, MUFA, and PUFA were not significantly different ( $p \geq 0.05)$. However, the value of omega 3 and Omega 6 fatty acids recorded a significant difference $(\mathrm{p} \leq 0.05)$. Kakamega ecotype recorded the highest value of omega 3 as well as omega 6 composition. This was followed by Taita and finally, the Naivasha ecotype. Though many factors may have contributed to this including ecotype (Pavlovski et al., (2013), the other likely factor is that the feeding regime for chicken in Kakamega consists chiefly of free range in which they chicken scavenge on grasses, leaves, and worms. It is reported that the ratio of omega 6 to omega 3 fatty acids is higher in the feeds scavenged by chicken from natural diets than in what they are fed in cereals and legumes (Haug et al., 2011). In the other regions particularly Naivasha, the town influence resulted in farmers relying heavily on food from the hotels in town and some confessed to the use of waste from the dump site. The ratio of omega 6 to omega 3 is predictive of the quality of fat in diets. The current ratio in most western diets ranges between 20:1 and 
$30: 1$, though the ideal is agreed as 4:1 (Marangoni et al., 2015b). The Kakamega ecotype ratio of 9.5:1 is most favourable and is recommended in this regard.

The SFA content of chicken meat was contributed majorly by palmitic, myristic and stearic fatty acids both in breast (Pavlovski et al., 2013) and thigh (Table 2 and 3). Meat in general is associated with the supply of fatty acids especially the SFA which have been associated with the risk of cardiovascular diseases (Milićević et al., 2014). The SFA has been reported to be significantly different between breeds for example naked neck and the broiler (hybro $\mathrm{G}+$ and Cobb 308) (Pavlovski et al., 2013). Fatty acid profiles were also reported to differ significantly $(p \leq 0.05)$ with the part of the body (Pavlovski et al., 2013; Adulyatham et al., 2006). Poultry meat is considered healthier because of a considerably low fat content compared to other meats (Brenes and Roura, 2010). Lipids of animal origin typically contain triglycerides (Abdulla et al., 2015). Similar data expressing the values of the fatty acids on the breast muscles of the three ecotypes is presented in figure 2. There was a significant difference $(\mathrm{p} \leq 0.05)$ in the MUFA content of the thighs of the ecotypes (Naivasha and Taita) which had higher values than that of the Kakamega chicken. The Kakamega ecotype had significantly higher value of the Omega 6 fatty acids than the Naivasha and Taita ecotypes.

Table 4: \% amount, ratio of average values of $\square-6$ : $\square-3$ fatty acids for ecotype and body part vs. recommended ratio

\begin{tabular}{|c|c|c|c|c|c|}
\hline Ecotype & Chicken part & Omega 6 & Omega 3 & Ratio & $\begin{array}{l}\text { Recommended } \\
\text { ratio }\end{array}$ \\
\hline \multirow[t]{3}{*}{ Kakamega } & Breast & $12.64 \pm 0.81$ & $1.32 \pm 0.19$ & $9.5: 1$ & $4: 1$ \\
\hline & Thigh & $13.18 \pm 0.63$ & $1.41 \pm 0.18$ & $9.0: 1$ & \\
\hline & Average & $12.91 \pm 0.51$ & $1.36 \pm 0.13$ & $9.5: 1$ & \\
\hline \multirow[t]{3}{*}{ Naivasha } & Breast & $13.12 \pm 0.32$ & $1.01 \pm 0.07$ & 13.0:1 & $4: 1$ \\
\hline & Thigh & $14.09 \pm 0.72$ & $1.00 \pm 0.18$ & 14.0:1 & \\
\hline & Average & $13.60 \pm 0.40$ & $1.01 \pm 0.10$ & $13.5: 1$ & \\
\hline \multirow[t]{3}{*}{ Taita } & Breast & $12.94 \pm 0.76$ & $1.11 \pm 0.09$ & 11.7:1 & $4: 1$ \\
\hline & Thigh & $14.24 \pm 1.57$ & $1.08 \pm 0.12$ & 13.2:1 & \\
\hline & Average & $13.59 \pm 0.87$ & $1.10 \pm 0.08$ & $12.4: 1$ & \\
\hline
\end{tabular}

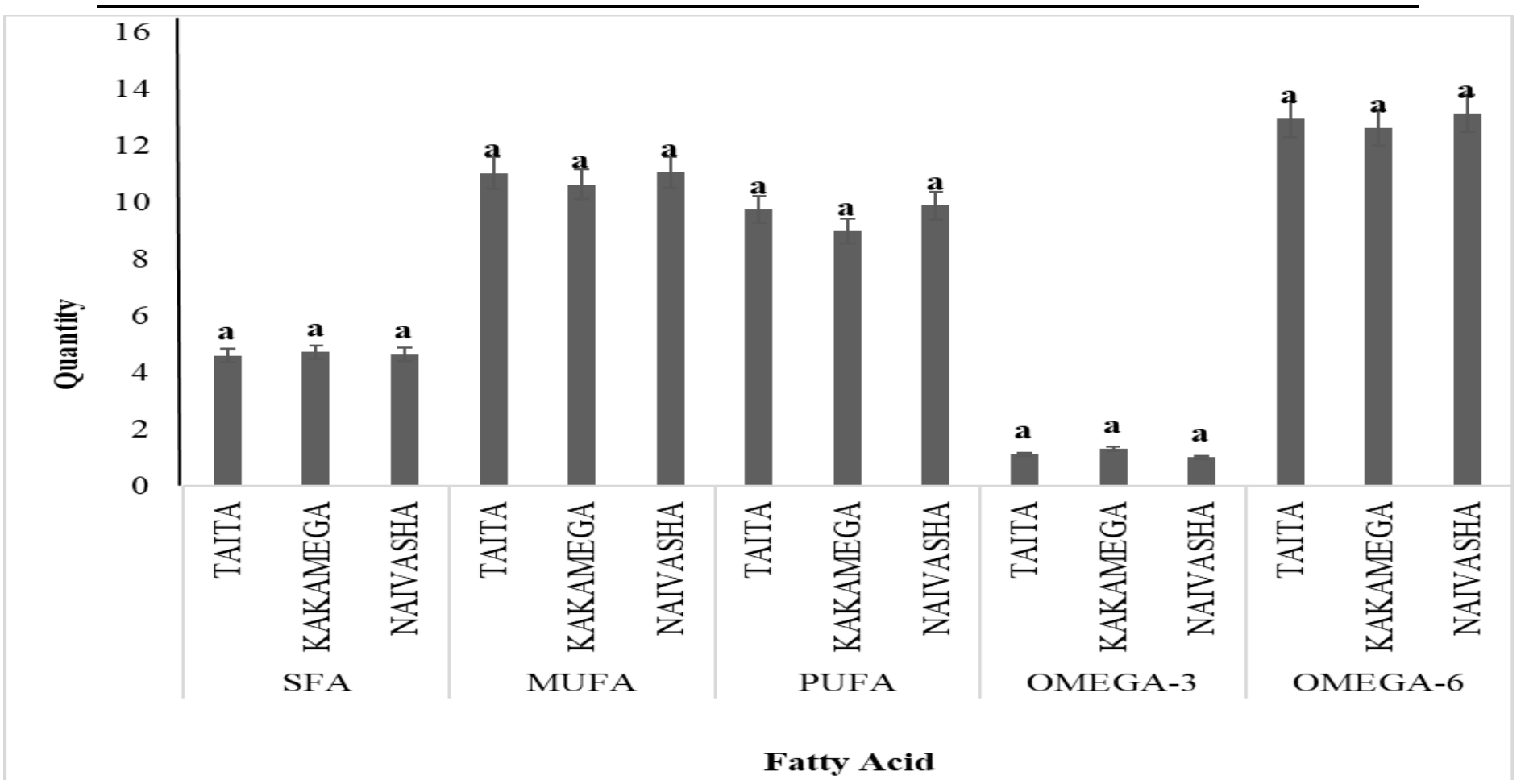

Figure 2: The fatty acids (\%) in breast meat of three Kenyan indigenous cluster ecotypes 


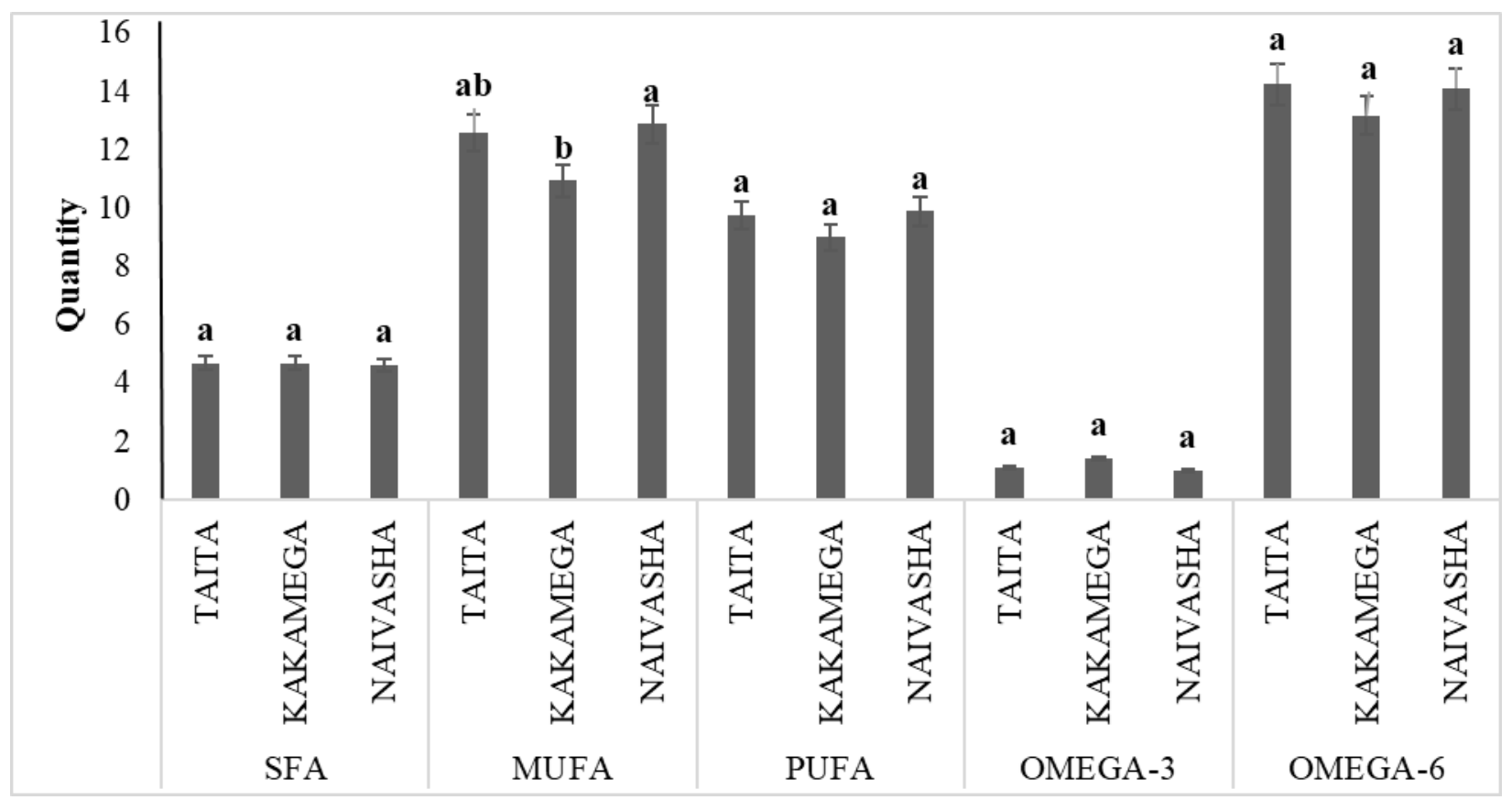

Fatty acid

\section{Figure 3: The fatty acids (\%) of thigh meat in three indigenous Kenyan cluster ecotypes}

In Brazil, no fatty acid content of local chicken was presented in their tables of food composition and same thing is true for Kenya (Almeida et al., 2006). Though the cholesterol levels of chicken meat have been reported to be more than that of the beef yet there is always reduction of the serum total cholesterol levels from consumption of beef and this could be explained as due to the type of PUFA in diet rather than cholesterol being the most potent regulator of the serum cholesterol. Maturation period of chicken has come down from the 120 days in 1970 to 45 days in the 2000s and currently, less, or as stated by the Centre for Food Integrity, 48 days at 6.2 pounds compared to 112 days and 2.5 pounds in 1925. This rate of growth has been achieved against an increase in high fat content, especially for those fed diets that ae rich in omega 6 and protein. Studies also show that palmitic oil in feeds directly contributes to the increase in palmitic acid concentration in chicken (Smink et al., 2008). Pastures provide good sources of omega-3 (Ponte et al., 2008); and usually consumer's desire for specialty poultry under free range for greater omega
3 and PUFA because these reduce the risk of cardiovascular disease (Tempe, 1996) and inhibits the growth of mammary and prostate gland tumors and cancers (Pandalai et al., 1996). The values and ratios of $\square-3$ and $\square-6$ are presented in Table 4 . The lowest ratio was recorded for Kakamega ecotype and it stood at 9:1. The often recommended ratio is $4: 1$. Phospholipids on the other hand is endowed with a higher composition of PUFA existing as cellular membrane contents (De Smet et al., 2004). Although red meats are high in phospholipids hence higher in PUFA, this characteristic is related to the prediction of possible lipid oxidation (Marangon et al., 2015). The PUFAs undergo rapid oxidation leading to impaired organoleptic quality, short shelf life and if uncontrolled, off flavours. Fatty acid composition or profile could be affected by dietary $\mathrm{Ca}^{2++}$ particularly for broilers (Abdulla et al., 2015). This is because it is believed that they form calcium soaps with fatty acids, resulting in decreased digestion and absorption of fat. Lipid oxidation causes deterioration, affects the colour, flavor, texture and nutritional value of poultry. 
Supplementation with natural antioxidants are a good supplement tool and is attractive to the products'wholesome nutritious benefits for the health conscious consumers (Kang et al., 2001). Oxidative stability of meat is decreased with increasing concentration of PUFA. The current results recorded lowest values of MUFA and PUFA for Kakamega ecotype than the other two which potentially may mean that these meats may experience higher oxidative stability (Figure 2 and 3). Lower TBARS due to feeding on palm oil (PO) resulted in increased PUFA hence more free radical formation and decreased oxidative stability of meats (Abdulla et al., 2015).

Whereas intensive chicken farming industry has since its inception in the USA in the 1960s allowed quantitative satisfaction with relatively cheap chicken all the year round-this is the reason that the price of chicken has decreased compared to other meat products. However, they also have poor quality (watery, insufficient taste, and lower aroma, more fat under the skin and abdominal cavity, with weak and brittle bones). This is different from the chicken meat characteristics of chicken reared under free range systems like the indigenous chicken in Kenya (Oloo et al., 2018). At the same time, the consumers are concerned about welfare and food safety threats that may arise as a result of keeping thousands of chicken is such close proximity. This practice leads to an emergence of the perception that broiler meat is not really healthy and natural (Škrbić et al., 2012). Van Marle-Koster and Webb (2000), observed that in some cases, though chicken received the same diet, differences in such meat components as unsaturated fatty acid were observed. They suggested that the observed differences could have resulted from the eating behavior of the individual breeds with the indigenous chicken tending to scratch while feeding and to pick feed particles more selectively than the broiler. This case may also explain the slight differences in the nutritional quality between the indigenous chicken ecotypes since those especially Naivasha are fed in-house and are released to graze for fewer hours on average than the Kakamega ecotypes. From the health point of view, Jaturasitha et al. (2008) noted that indigenous chicken could be superior because their fat and cholesterol contents were low and fatty acid profile is favourable. Our finding seems to support this assertion especially with regard to the amino acid profile.

\section{CONCLUSION}

This study revealed significant amounts of amino acid and fatty acid in three ecotypes of indigenous chicken of Kenya. Glutamic acid was the highest amino acid while the lowest value recorded was for Histidine. Hewever, all the reported amino acid values exceeded the recommended intakes by WHO/FAO for adults and children. The high value of Glutamic amino could be related to the good taste proclaimed by consumers of indigenous chicken. There was no significant difference among the values of PUFA, MUFA, and SFA for breast and thigh. The lowest ratio of Omega-6:Omega-3 was 9:1 and was lower than the recommended value of 4:1. The Kakamega ecotype had the lowest ratio among the 3 ecotypes, which points to the superiority of this ecotype with regard to this parameter. Free-range rearing as applied to indigenous chicken results in a favourable Omega-6:Omega-3 ratio, though this was still lower than the recommended ratio.

\section{ACKNOWLEDGEMENT}

The authors appreciate the support of Egerton University's Department of Dairy \& Food Science \& Technology and the Department of Biotechnology and Food Technology of Durban University of Technology (DUT), South Africa, for availing laboratory facilities to the authors for this work. The authors also specially recognize Ms. Samantha Govender and Nyasha Mirriam Busu of the Food Science Laboratory (DUT) for laboratory work support and to Mr. Nobert Wafula of Egerton University for data analysis help. This work was partially funded by a research grant from the Kenya National Council for Science, Technology and Innovation (NACOSTI). 


\section{REFERENCES}

Abdulla, N.R., Loh, T.C., Akit, H., Sazili, A.Q., Foo, H.L., Mohamad, R., Rahim, R.A., Ebrahimi, M. \& Sabow, A.B. (2015). Fatty acid profile, cholesterol and oxidative status in broiler chicken breast muscle fed different dietary oil sources and calcium levels. South African Journal of Animal Science 45, 153-163.

Adulyatham, P., Wattanachant, S., Wattanachant, C. \& Wattanasit, S. (2006). Some physical characteristics and sensory evaluation of naked-neck and indigenous chickens compared with broiler. In: Proc. of 5th of the Southern Animal Science Conference. p. 307-318.

Almeida, J.C. de, Perassolo, M.S., Camargo, J.L., Bragagnolo, N. \& Gross, J.L. (2006). Fatty acid composition and cholesterol content of beef and chicken meat in Southern Brazil. Revista Brasileira de Ciências Farmacêuticas 42, $109-117$.

American Diabetes Association. (2005). Defining and reporting hypoglycemia in diabetes: a report from the American Diabetes Association Workgroup on Hypoglycemia. Diabetes care 28, 1245-1249.

AOAC. (2005). Official Methods of Analysis, 16th Edition, Association of Official Analytical Chemists, Arlington.

Aronal, A.P., Huda, N. \& Ahmad, R. (2012). Amino Acid and Fatty Acid Profiles of Peking and Muscovy Duck Meat. International Journal of Poultry Science 11, 229-236.

Bidlingmeyer, B.A., Cohen, S.A. \& Tarvin, T.L. (1984). Rapid analysis of amino acids using pre-column derivatization. Journal of Chromatography B: Biomedical Sciences and Applications 336, 93-104.

Blagojević, M., Pavlovski, Z., Škrbić, Z., Lukić, M., Milošević, N. \& Perić, L. (2009). The effect of genotype of broiler chickens on carcass quality in extensive rearing system. Acta veterinaria 59, 91-97.

Bogosavljevic-Boskovic, S., Mitrovic, S., Djokovic, R., Doskovic, V. \& Djermanovic, V. (2010). Chemical composition of chicken meat produced in extensive indoor and free range rearing systems. African Journal of Biotechnology 9 , 9069-9075.

Brenes, A. \& Roura, E. (2010). Essential oils in poultry nutrition: Main effects and modes of action. Animal Feed Science and Technology 158, 1-14.

Cherian, G., Selvaraj, R.K., Goeger, M.P. \& Stitt, P.A. (2002). Muscle fatty acid composition and thiobarbituric acidreactive substances of broilers fed different cultivars of sorghum. Poultry science 81, 1415-1420.

Dawkins, M.S. (2003). Behaviour as a tool in the assessment of animal welfare. Zoology 106, 383-387.

FAO/WHO. (1985). Energy and Protein Requirements: Report of a Joint FAO/WHO/UNU Expert Consultation. WHO.

FAO/WHO. (1991). Protein Quality Evaluation: Report of the Joint FAO/WHO Expert Consultation, Bethesda, Md., USA 4-8 December 1989. Food \& Agriculture Org.

FAO. (2014). FAOSTAT http://faostat.fao.org/default.aspx, 2012.

Farmer, L.J. (1999). Poultry meat flavor. Poultry meat science 127-158.

Gross, J.L., Zelmanovitz, T., Moulin, C.C., Mello, V. De, Perassolo, M., Leitão, C., Hoefel, A., Paggi, A. \& Azevedo, M.J. (2002). Effect of a chicken-based diet on renal function and lipid profile in patients with type 2 diabetes: a randomized crossover trial. Diabetes care 25, 645-651.

Haug, A., Christophersen, O.A. \& Sogn, T. (2011). Chicken meat rich in selenium and omega-3 fatty acids. The Open Agriculture Journal 5, 30-36.

Heinz, G., Hautzinger, P. \& Hautzinger, P. (2007). Meat processing technology for small- to medium- scale producers. (this is ncomplete). FAO, Bangkok (Thailand)

Hoffman, L.C., Kritzinger, B. \& Ferreira, A. V. (2005). The effects of region and gender on the fatty acid, amino acid, mineral, myoglobin and collagen contents of impala (Aepyceros melampus) meat. Meat Science 69, 551-558.

Indarti, E. (2015). Preparation of biodiesel from microalgae and palm oil by direct transesterification in a batch microwave reactor. In: Journal of Physics: Conference Series. P. 12040. IOP Publishing.

Jaturasitha, S., Srikanchai, T., Kreuzer, M. \& Wicke, M. (2008). Differences in carcass and meat characteristics between chicken indigenous to Northern Thailand (Black-Boned and Thai native) and imported extensive breeds (Bresse and Rhode Island Red). Poultry Science 87, 160-169.

Kang, J.O., Kim, S.J. \& Kim, H. (2001). Effect of astaxanthin on the hepatotoxicity, lipid peroxidation and antioxidative enzymes in the liver of CCl. Methods Find Exp Clin Pharmacol 23, 79-84.

Leosdottir, M., Nilsson, P.M., NILSSON, J., Månsson, H. \& Berglund, G. (2005). Dietary fat intake and early mortality patterns-data from The Malmö Diet and Cancer Study. Journal of Internal Medicine 258, 153-165.

Marangoni, F., Corsello, G., Cricelli, C., Ferrara, N., Ghiselli, A., Lucchin, L. \& Poli, A. (2015a). Role of poultry meat in a balanced diet aimed at maintaining health and wellbeing: An Italian consensus document. Food and Nutrition 
Research 59, 1-11.

Marangoni, F., Corsello, G., Cricelli, C., Ferrara, N., Ghiselli, A., Lucchin, L., Poli, A., Mandal, G.P., Ghosh, T.K., Patra, A.K., Ogeto, V., Science, E., R, S.P.R., Suriani, N.W., Purnomo, H., Estiasih, T., Suwetja, I.K., Motsepe, R., Mabelebele, M., Norris, D., Brown, D., Ngambi, J., Ginindza, M., Cherian, G., Selvaraj, R.K., Goeger, M.P., Stitt, P.A., Straková, E., Suchý, P., Herzig, I., Hudečková, P., Ivanko, Š., Suazo, R.V.C., Rivero, H., Suriani, N.W., Purnomo, H., Estiasih, T., Suwetja, I.K., Abdulla, N.R.N., Loh, T.T.C., Akit, H., Sazili, A.A.Q., Foo, H.L.H., Mohamad, R., Abdul Rahim, R., Ebrahimi, M., Sabow, A.B.A., Almeida, J.C. de, Perassolo, M.S., Camargo, J.L., Bragagnolo, N., Gross, J.L., Pavlovski, Zlatica, Z.-B., Škrbić, Zdenka, Z.-B., Stanišić, Nikola, B.-Z., Lilić, S.B. Hengl, B.O., Lukić, Miloš, Z.-B., Petričević, Veselin Z.-B., Milićević, D., Vranić, D., Mašić, Z., Parunović, N., Trbović, D., Nedeljković-Trailović, J., Petrović, Z., Haug, A., Abdulla, N.R.N., Loh, T.T.C., Akit, H., Sazili, A.A.Q., Foo, H.L.H., Mohamad, R., Abdul Rahim, R., Ebrahimi, M., Sabow, A.B.A., Almeida, J.C. de, Perassolo, M.S., Camargo, J.L., Bragagnolo, N., Gross, J.L., Gunstone, F., Molee, W., Puttaraksa, P., Khempaka, S., Jeon, H.J., Choe, J.H., Jung, Y., Kruk, Z.A., Lim, D.G. \& Jo, C. (2015b). Differences in fatty acid composition of meat between naked neck and two commercial broiler chicken breeds. International Journal of Chem Tech Research 1, $467-476$.

Marle-Koster, E. Van \& Webb, E.C. (2000). Carcass characteristics of South African native chicken lines. South African Journal of Animal Science 30, 53-56.

Milićević, D., Vranić, D., Mašić, Z., Parunović, N., Trbović, D., Nedeljković-Trailović, J. \& Petrović, Z. (2014). The role of total fats, saturated/unsaturated fatty acids and cholesterol content in chicken meat as cardiovascular risk factors. Lipids in health and disease 13, 42.

Milosevic, N., Peric, L., \& Supic, B. (2003). Raising chickens on a free range system. 1. Evaluation of carcass quality. biotechnology in animal husbandry. Institute for A nimal Husbandry, Belgrade-Zemun, 317-325.

Oloo, B.O., Mahungu, S. \& Kahi, A. (2018). Descriptive sensory quality of Kenya's indigenous chicken meat from different ecotype-clusters reared under an intensive system. African Journal of Food, Agriculture, Nutrition and Development 18.

Pandalai, P.K., Pilat, M.J., Yamazaki, K., Naik, H. \& Pienta, K.J. (1996). The effects of omega-3 and omega-6 fatty acids on in vitro prostate cancer growth. Anticancer research, 16, 815-820.

Pavlovski, Z., Škrbić, Z., Stanišić, N., Lilić, S., Hengl, B., Lukić, M. \& Petričević, V. (2013). Differences in fatty acid composition of meat between naked neck and two commercial broiler chicken breeds. Biotechnology in Animal Husbandry 29, 467-476.

Rand, W.M., Pennington, J.A.T., Murphy, S.P. \& Klensin, J.C. (1991). Compiling data for food composition data bases. United Nations University Press, Tokyo.

Škrbić, Z., Pavlovski, Z., Lukić, M., Petričević, V. \& Milić, D. (2012). The effect of lighting program and type of litter on production and carcass performance of two broiler genotypes. Biotechnology in Animal Husbandry 28, 807816.

Smet, S. De, Raes, K. \& Demeyer, D. (2004). Meat fatty acid composition as affected by fatness and genetic factors: a review. Animal Research 53, 81-98.

Smink, W., Gerrits, W.J.J., Hovenier, R., Geelen, M.J.H., Lobee, H.W.J., Verstegen, M.W.A. \& Beynen, A.C. (2008). Fatty Acid Digestion and Deposition in Broiler Chickens Fed Diets Containing Either Native or Randomized Palm Oil. Poultry Science 87, 506-513.

Wattanachant, S., Benjakul, S. \& Ledward, D.A. (2004). Composition, color, and texture of Thai indigenous and broiler chicken muscles. Poultry science 83, 123-128.

Wood, J. D., Enser, M., Fisher, A. V., Nute, G. R., Sheard, P. R., Richardson, R. I., ... \& Whittington, F. M. (2008). Fat deposition, fatty acid composition and meat quality: A review. Meat science, 78(4), 343-358.

Zootecnica. (2016). The poultry sector in Kenya. Accessed from https://zootecnicainternational.com/field-reports/poultry -sector-kenya/ on $1^{\text {st }}$ July, 2019. 